\title{
Interprofessional Primary Care Course Curriculum and Evaluation
}

William R. Phillips, MD, MPH; Toby Keys, MA, MPH

BACKGROUND AND OBJECTIVES: Primary care (PC) requires interprofessional teamwork and training. Although clinical training in PC settings is well developed in some professions, classroom teaching on the principles and practice of PC provides additional opportunities for interprofessional education.

METHODS: We offered an elective one-credit classroom course on PC over 3 years, 2013 through 2015, enrolling students from dentistry, medicine, nursing, pharmacy, physician assistant, public health, social work, and other fields. Course activities included classroom presentations, small group discussions, team exercises, written reflections, online discussion, and observation visits to PC practices. We conducted an anonymous postcourse evaluation using 5-point Likert-like scales and brief student comments.

RESULTS: Eighty-four students completed the course over 3 years and $86 \%$ (72) completed the evaluation. Students rated the course high value or very high value, particularly for interprofessional student mix $(99 \%, 71)$ and practice visit $(99 \%, 70 / 71)$. Most students $(98 \%, 65 / 66)$, felt the course should be offered again, and $82 \%(54 / 66)$ thought it should be expanded. Most students $(93 \%, 65 / 70)$, recommended the course for others, and $41.1 \%(29 / 70)$ felt it should be required for students in their field or for all health professions students. After completing the course, 83.3\% (60/72) of students planned careers in PC settings, and $55.6 \%(40 / 72)$ reported they changed plans to such careers.

CONCLUSIONS: The PC course served students across health professions, earned high ratings, and influenced PC career plans. Most students felt the course should be recommended or required for all health professions students.

(Fam Med. 2018;50(3):217-22.)

doi: 10.22454/FamMed.2018.998057

nterprofessional health care teams are essential for effective primary care practice and training. ${ }^{1-3}$ Medicine, ${ }^{4}$ nursing, and physician assistants have developed clinical primary care (PC) training programs, ${ }^{5}$ but other important members of PC teams have limited opportunities for PC training. Few programs teach the principles of $\mathrm{PC}$ and the role of PC in the health of individuals and populations. ${ }^{6}$ Interprofessional classroom learning can enhance understanding of PC across professional groups and build a shared foundation for practice, scholarship, advocacy, and leadership.,8

We created a novel interprofessional classroom course in PC and describe here the content, educational methods, evaluation, and student recommendations for further development.

\section{Methods}

The department of family medicine offered the primary care course (PCC) to all graduate and professional students as a 12-week, one-credit ungraded course. Class size of 25 to 30 accommodated approximately four students from each of seven groups: dentistry, medicine, nursing, pharmacy, physician assistants, public health, and social work.

We recruited students from across the health sciences campus and broader university using personal contact with program advisors, posters, and a website advertising:

This unique interprofessional course focuses on primary care, the foundation of medicine and the cornerstone of health care reform. Discusses clinical, training, workforce, delivery, quality and policy. Describes the role of primary care in personal and population health.

From the Department of Family Medicine, University of Washington. 
Explores care teams and the $\mathrm{Pa}$ tient-Centered Medical Home. Includes presentations, discussion and practice visits. All professional and graduate students welcome!

The course was not a typical survey course, but presented $\mathrm{PC}$ as a unified domain of scientific knowledge and professional expertise. To model three key principles of primary care-generalism, comprehensiveness, and continuity-all sessions were led by one instructor (WRP).

Curriculum content is outlined in Table 1. Topic modules included class presentations, readings, and discussion questions. Class sessions involved problem-solving exercises for small groups mixing students from each profession.

Each student made a half-day practice visit to observe a PC clinician (most family physicians) seeing patients. We provided nonclinical students materials to help prepare for their first patient care experience. All students completed Health Insurance Portability and Accountability Act training. Clinicians used their established patient consent procedures. The study was exempted by the University of Washington Institutional Review Board.

We conducted an anonymous webbased evaluation survey. Students rated satisfaction on a 5-point Likert-like scale: 1-Very Low Value,
2-Low Value, 3-OK Value, 4-High Value, 5-Very High Value, or No Opinion. Some questions asked for True or False responses, short comments, or recommendations for improvement.

\section{Results}

Eighty-four students completed the PC course over 3 years 2013 through 2015 , with $64 \%$ (54) women, representing each health profession and ranging from undergraduates to postdoctoral trainees (Table 2). Student academic level ranged from undergraduate $(3,3.6 \%)$ to master's degree $(24,28.6 \%)$, professional doctorate $(41,48.8 \%), \mathrm{PhD}(3,3.6 \%)$ and postdoctoral trainee $(4,4.7 \%)$.

Table 1: Primary Care Course Curriculum Outline

\begin{tabular}{|c|c|}
\hline $\begin{array}{l}\text { - Starting from common } \\
\text { - Primary care is a team } \\
\text { - PC provides most of the }\end{array}$ & $\begin{array}{l}\text { Organizing Themes } \\
\text { lealth care system is a shared catastrophe. } \\
\text { illage to provide primary care. } \\
\text { te people for most of their problems most of the time. }\end{array}$ \\
\hline Definition of PC & $\begin{array}{l}\text { IOM, Alma Atta Declaration, WHO Primary Health Care } \\
\text { What PC is not }\end{array}$ \\
\hline Principles of PC & $\begin{array}{l}\text { Comprehensive, Continuity, Community, Context } \\
\text { Whole person care }\end{array}$ \\
\hline Populations served by PC & Underserved, Vulnerable, Urban and Rural \\
\hline Clinical content of $\mathrm{PC}$ & $\begin{array}{l}\text { Acute, chronic, prevention, mental health } \\
\text { Specialize in common problems vs diagnoses } \\
\text { Multiple problems and patients at one visit }\end{array}$ \\
\hline Comprehensive Care & $\begin{array}{l}\text { Cradle to grave, family care, coordination of care } \\
\text { Patient-centered care } \\
\text { Relationship-centered care }\end{array}$ \\
\hline $\begin{array}{l}\text { PC and the health of } \\
\text { - the people } \\
\text { - the individual }\end{array}$ & $\begin{array}{l}\text { Access, quality, outcomes, patient experience, cost } \\
\text { International, US national and regional evidence } \\
\text { Triple Aim, Quadruple Aim }\end{array}$ \\
\hline PC clinicans & Training, scope of practice, options for focus \\
\hline PC delivery models & $\begin{array}{l}\text { Integrated health care systems } \\
\text { Chronic Care Model } \\
\text { Patient-Centered Medical Home }\end{array}$ \\
\hline Teamwork in PC & $\begin{array}{l}\text { Patient as team member } \\
\text { Roles in teams: DDS, MD/DO, PA, RN, NP, PharmD, PH, MSW } \\
\text { Complementary relationships with other specialists }\end{array}$ \\
\hline $\mathrm{PC}$ in context & $\begin{array}{l}\text { Values of generalism and specialism } \\
\text { Inverse Care Law, Primary Care Paradox }\end{array}$ \\
\hline $\mathrm{PC}$ research & $\begin{array}{l}\text { Practice-based research networks } \\
\text { Community-based participatory research } \\
\text { Ecology of medical care }\end{array}$ \\
\hline Future of PC & $\begin{array}{l}\text { PC in the US health care system } \\
\text { Challenges facing primary care } \\
\text { Health care reform - Future models of health care }\end{array}$ \\
\hline
\end{tabular}


Table 2: Student Profession, Training Program and Characteristics in Primary Care Course

\begin{tabular}{|c|c|c|c|c|c|}
\hline & \multicolumn{4}{|c|}{ Students } \\
\hline & & $\begin{array}{c}\text { Course Year } \\
2013\end{array}$ & $\begin{array}{c}\text { Course Year } \\
2014\end{array}$ & $\begin{array}{l}\text { Course Year } \\
2015\end{array}$ & Total \\
\hline \multicolumn{2}{|l|}{ Total students } & $\begin{array}{c}24 \\
28.6 \%\end{array}$ & $\begin{array}{c}31 \\
36.9 \%\end{array}$ & $\begin{array}{c}29 \\
34.5 \%\end{array}$ & $\begin{array}{c}84 \\
100 \%\end{array}$ \\
\hline Academic Unit & \multicolumn{5}{|l|}{ Degree Programs } \\
\hline School of dentistry & $\begin{array}{l}\text { DDS } \\
\text { MSD-Pediatric Dentistry }\end{array}$ & 5 & 0 & 2 & $\begin{array}{c}7 \\
8.3 \%\end{array}$ \\
\hline School of medicine & $\mathrm{MD}, \mathrm{MD} / \mathrm{MPH}, \mathrm{MD} / \mathrm{PhD}$ & 6 & 5 & 5 & $\begin{array}{c}16 \\
19.0 \%\end{array}$ \\
\hline School of nursing & $\begin{array}{l}\text { BSN, MN, PhD } \\
\text { DNP-Nurse Practitioner } \\
\text { DNP-Nurse Specialist } \\
\text { Nurse Midwifery }\end{array}$ & 1 & 6 & 4 & $\begin{array}{c}11 \\
13.1 \%\end{array}$ \\
\hline School of pharmacy & PharmD & 2 & 6 & 6 & $\begin{array}{c}14 \\
16.7 \%\end{array}$ \\
\hline Physician assistant program & $\begin{array}{l}\text { PA, BCHS, MCHS } \\
\text { (Clinical Health Services) }\end{array}$ & 0 & 5 & 4 & $\begin{array}{c}9 \\
10.7 \%\end{array}$ \\
\hline School of public health & $\begin{array}{l}\text { MPH, PhD } \\
\text { MHA - Hospital Admin. }\end{array}$ & 7 & $\begin{array}{l}5 \\
1\end{array}$ & $\begin{array}{l}3 \\
1\end{array}$ & $\begin{array}{c}17 \\
20.2 \%\end{array}$ \\
\hline School of social work & MSW, MSW/MPH & 3 & 2 & 3 & $\begin{array}{c}8 \\
9.5 \% \\
\end{array}$ \\
\hline Others & $\begin{array}{l}\text { Business - MBA } \\
\text { Post-BS Global Health }\end{array}$ & 0 & 1 & 1 & $\begin{array}{c}2 \\
2.4 \%\end{array}$ \\
\hline \multicolumn{6}{|l|}{ Student Level } \\
\hline Bachelor degree & & 0 & 2 & 1 & $\begin{array}{c}3 \\
3.6 \%\end{array}$ \\
\hline Physician assistant & & 0 & 5 & 4 & $\begin{array}{c}9 \\
10.7 \%\end{array}$ \\
\hline Master's degree & & 9 & 8 & 7 & $\begin{array}{c}24 \\
28.6 \%\end{array}$ \\
\hline Professional doctorate & & 10 & 15 & 16 & $\begin{array}{c}41 \\
48.8 \%\end{array}$ \\
\hline $\mathrm{PhD}$ & & 1 & 1 & 1 & $\begin{array}{c}3 \\
3.6 \%\end{array}$ \\
\hline Postdoctoral & & 4 & 0 & 0 & $\begin{array}{c}4 \\
4.7 \%\end{array}$ \\
\hline \multicolumn{6}{|l|}{ Gender } \\
\hline Women & & 17 & 17 & 20 & $\begin{array}{c}54 \\
64.3 \%\end{array}$ \\
\hline Men & & 7 & 14 & 9 & $\begin{array}{c}30 \\
35.7 \%\end{array}$ \\
\hline Total & & $\begin{array}{c}24 \\
28.6 \%\end{array}$ & $\begin{array}{c}\mathbf{3 1} \\
\mathbf{3 6 . 9} \%\end{array}$ & $\begin{array}{c}29 \\
34.5 \%\end{array}$ & $\begin{array}{c}84 \\
100 \%\end{array}$ \\
\hline
\end{tabular}

Physician assistant students (9, $10.7 \%$ ) can be in bachelor's or master's degree programs.

All students in clinical professional programs $(65,77.4 \%)$, regardless of their level of training, had substantial patient care experience prior to the course, although often no exposure to primary care settings. Most students from the nonclinical programs of public health, business, and global health $(19,22.6 \%)$ had no prior clinical experience.
The evaluation survey achieved an $86 \%$ response rate $(72 / 84)$ over 3 years (ranging from $83 \%$ to $90 \%$ ) and across professional groups (ranging from $75 \%$ (6/8) for MSW to $100 \%$ (7/7) for dentistry (Table 3). 
Table 3: Student Evaluation of Primary Care Course Over 3 Years

\begin{tabular}{|c|c|c|}
\hline $\begin{array}{l}\text { Course Activities and Materials } \\
\text { How valuable was ... ? (N=72)* }\end{array}$ & \multicolumn{2}{|c|}{$\begin{array}{l}\text { Percent of Respondents Rating Activity }{ }^{ \pm} \\
\text {HV-High Value or VH-Very High Value }\end{array}$} \\
\hline Interprofessional mix of students & $\begin{array}{l}\text { HV } 10 \\
\text { VH } 61\end{array}$ & $\begin{array}{l}99 \% \\
71 / 72\end{array}$ \\
\hline In-class discussions & $\begin{array}{l}\text { HV } 21 \\
\text { VH } 42\end{array}$ & $\begin{array}{l}88 \% \\
63 / 72\end{array}$ \\
\hline Student online discussion & $\begin{array}{l}\text { HV } 24 \\
\text { VH } 10\end{array}$ & $\begin{array}{l}47 \% \\
34 / 72\end{array}$ \\
\hline Instructor presentations & $\begin{array}{l}\text { HV } 29 \\
\text { VH } 34\end{array}$ & $\begin{array}{l}88 \% \\
63 / 72\end{array}$ \\
\hline Practice visit and observation & $\begin{array}{l}\text { HV } 16 \\
\text { VH } 54\end{array}$ & $\begin{array}{l}99 \% \\
70 / 71^{*}\end{array}$ \\
\hline Course website & $\begin{array}{l}\text { HV } 23 \\
\text { VH } 27\end{array}$ & $\begin{array}{l}69 \% \\
50 / 72\end{array}$ \\
\hline Course readings & $\begin{array}{l}\mathrm{HV} 33 \\
\mathrm{VH} 4\end{array}$ & $\begin{array}{l}51 \% \\
37 / 72 \\
\end{array}$ \\
\hline I wish we could have spent more time on activity ... $(\mathrm{N}=70)$ * & \multicolumn{2}{|c|}{ Percent (Number) Responding Yes } \\
\hline Instructor's case stories & \multicolumn{2}{|c|}{$67 \%(47 / 70)$} \\
\hline Full class discussion & \multicolumn{2}{|c|}{$43 \%(30 / 70)$} \\
\hline Small group discussion & \multicolumn{2}{|c|}{$40 \%(28 / 70)$} \\
\hline Lectures/presentations & \multicolumn{2}{|c|}{$29 \%(20 / 70)$} \\
\hline
\end{tabular}

* 84 students completed the course, $72(85.7 \%)$ students responded to survey. Number of students responding varied slightly by question. One student did not make a practice observation.

${ }^{ \pm}$Rated on 5-point scale: 1-Very Low Value, 2-Low Value, 3-OK Value, 4-High Value, 5-Very High Value.

Students rated all course activities as 4-High Value or 5-Very High Value on the 5-point scale. Student comments highlight their positive assessments (Table 4).

Almost all students (99\%, 71/72), valued the interprofessional student mix. Students also valued class discussions $(88 \%, 63 / 72)$, with equal numbers preferring small group vs whole class discussions.

For most students $(99 \%, 70 / 71)$, the practice observation visit was the highlight of the course. Many described it as "a life changing experience." Discussions returned again and again to examples students shared from their practice visits. In just a brief visit, students saw moving evidence of the principles of PC at work with real patients, problems, and professionals. Students immediately appreciated the depth and breadth of PC and the value of continuing patient-clinician relationships. They saw PC teams at work, witnessed joys of patient care, and felt frustrations with the health care system.

We asked students: "Did the PC course influence your interest in working in a PC setting in your career?" Fully $83.3 \%$ (60/72) reported they were interested in careers in PC, and $55.6 \%$ (40/72) reported the course increased that interest, including students in each professional group. Another 27.8\% (20/72) had planned PC careers before the course (Table 5).

Almost all students, 98\% (65/66), recommended we offer the course again, and $82 \%$ (54/66) felt it should be expanded by adding more class time and credits, an in-depth seminar or survey course with variety of topics and speakers (Table 6). Most students $(93 \%, 65 / 70)$, recommended the course for other students, and $41.4 \%$ (29/70) felt it should be required for students in their own professional field or for all health professions students.

\section{Discussion}

Our new PC course attracted a rich mix of health professions trainees and earned very high evaluation scores. Students most valued the interprofessional discussions and seeing PC clinicians care for patients. The experience recruited many students to PC careers. They recommended the course be offered or required for trainees in all health professions.

To our knowledge, this is the first such course described. It clearly filled needs felt by students who see futures in PC practice but worry their siloed training does not offer the information, experience, and perspectives they need. Our course evaluation achieved a high response rate over 3 years and demonstrated high scores from students across health professions schools. 
Table 4: Student Comments From Anonymous Course Evaluation Survey

\begin{tabular}{|c|}
\hline Verbatim Student Comments \\
\hline $\begin{array}{l}\text { Overall course evaluation } \\
\text { "Thank you for taking the time to show us about primary care. This course was truly the most interesting and } \\
\text { enlightening course that I have taken during my professional school career." - PharmD student, } 2015\end{array}$ \\
\hline $\begin{array}{l}\text { Interprofessional student mix } \\
\text { "This was a great and interesting course! I especially loved that it was an inter-disciplinary group. I wish we had more } \\
\text { classes like this in all of our programs." - Nursing trainee, } 2015\end{array}$ \\
\hline $\begin{array}{l}\text { Class discussions } \\
\text { "This course was just amazing and a breath of fresh air from my usual core class work. It was nice to come in and } \\
\text { discuss about the world and profession that is primary care. There is a special, unique quality of this class that will make } \\
\text { it one of my memorable classes here at the UW." - PharmD student, } 2014\end{array}$ \\
\hline $\begin{array}{l}\text { Practice observation visit } \\
\text { "If I hadn't seen it, I never would've believed it." - PharmD student, } 2013 .\end{array}$ \\
\hline $\begin{array}{l}\text { Instructor presentations } \\
\text { "Wonderful course overall... Thank you for sharing your stories with us as a class and teaching us strong values and } \\
\text { pillars for primary care." - MD student, } 2015 \\
\text { "[The instructor] led us on a journey through many realms related to primary care. He had a profound influence on my } \\
\text { relationship to PC. I so appreciated his personal stories... I learned a lot." - PA student, } 2015\end{array}$ \\
\hline $\begin{array}{l}\text { Impact of course on interest in working in a PC setting in your career } \\
\text { "Before this class I was much more interested in having a specialty rather than primary care. However, after attending } \\
\text { this class, I became much more fascinated by primary care and especially the interaction that I could have with my } \\
\text { patients in practice." - MD/MPH student, } 2014\end{array}$ \\
\hline $\begin{array}{l}\text { Course should be required for all health professions students } \\
\text { "This was a fantastic class and I am so glad I took it. I hope that all students in the healthcare professions are able to } \\
\text { participate and learn in the way that I did." - Nursing trainee, } 2014 \\
\text { "I think, as an institution focused on Primary Care, it is shocking that this course is not mandatory. Anyone in the } \\
\text { health sciences should be required to take this." - Nursing trainee, } 2015\end{array}$ \\
\hline
\end{tabular}

Comments from 72 students 2013-2015, responding to anonymous course evaluation survey. Students were identified only by professional group and course year.

Table 5: Influence of the Primary Care Course on Student Interest in a Primary Care Career

\begin{tabular}{|l|c|}
\multicolumn{1}{|c|}{$\begin{array}{c}\text { Did the PC course influence your interest in } \\
\text { working in a PC setting in your career? }\end{array}$} & Students \% (Number) \\
\hline More interested in PC career - total & $55.6 \%(40)$ \\
- somewhat more interested & $29.2 \%(21)$ \\
- much more interested in PC & $26.4 \%(19)$ \\
\hline No change-I already planned a PC career. & $27.8 \%(20)$ \\
\hline No change in plans & $16.7 \%(12)$ \\
\hline Considering PC career after course & $83.3 \%(60)$ \\
\hline Total & $(40+20)$ \\
\hline
\end{tabular}

$\mathrm{N}=72$. Of 84 total students, $(85.7 \%, 72 / 84)$ responded to this question.

"More interested in PC career-total" includes the sum of students somewhat more and very much more interested in PC careers.

"Considering PC career after course" includes sum of students more interested and students already considering PC careers.

Still, our experience is limited, coming from one institution with a strong PC orientation. Students were self-selected and cannot represent all students. Student plans for careers in PC settings may change over time.
The course was largely developed and taught by one instructor to model a generalist perspective, comprehensive view of $\mathrm{PC}$, and continuity of teacher-class relationship. We built on a family medicine orientation to
PC and matched most students with family physicians. Broader involvement of PC perspectives could enrich course content, teaching methods, and student experiences. , $^{3,5}$ 
Table 6: Student Recommendations for Primary Care Course

\begin{tabular}{|c|c|}
\hline \multicolumn{2}{|c|}{ Would you recommend course to other students? $(\mathrm{N}=70)$ * } \\
\hline Student Recommendation & Percent (Number) Responding Yes \\
\hline Recommend to other students & $93 \%(65 / 70)$ \\
\hline Recommend to all students & $59 \%(41 / 70)$ \\
\hline $\begin{array}{l}\text { Should be a required course } \\
\text { - Require for all students in my field } \\
\text { - Require for all health professions students }\end{array}$ & $\begin{array}{l}41 \%(29 / 70) \\
10 \%(7 / 70) \\
31 \%(22 / 70)\end{array}$ \\
\hline \multicolumn{2}{|c|}{ Recommendation for Future of PC Course $(\mathrm{N}=66)^{*}$} \\
\hline Offer course again & $98 \%(65 / 66)$ \\
\hline Expand classes, time and credits & $82 \%(54 / 66)$ \\
\hline Add a seminar course for in-depth study & $58 \%(38 / 66)$ \\
\hline Add a survey course with variety of topics and speakers & $58 \%(38 / 66)$ \\
\hline
\end{tabular}

*N=84 students completed the course, 72 students responded to survey. Number of students responding varied slightly by question.

Students could make multiple recommendations.

We encourage others to develop classroom courses and other interdisciplinary training opportunities in PC. Opportunities should be expanded to include seminar courses for deeper study of critical issues and survey courses to offer a broader variety of perspectives, clinicians, and topics. We are currently studying the longer-term impacts of this course on student knowledge and attitudes regarding PC and on career trajectory. Future studies should examine student outcomes in career choice, practice location, and outcomes of care. ${ }^{7,9}$

\section{Conclusions}

The PC course served students across health professions, earned high ratings, and influenced PC career plans. Students across health professions thirst for insight into PC. Many see their professional futures in PC, but know their training programs fall short in curriculum or expertise to inform their professional growth. Students also hunger for opportunities to learn with their colleagues in other professions. Courses that fill these needs can help meet our critical need for PC workforce, improve the function of clinical teams and improve understanding of PC throughout health care systems. Professionals with this training, experience, and perspective can contribute to improving individual and population health across our diverse communities.

ACKNOWLEDGMENTS: We thank Audrey Lew for course management and Jaime Grocock Fitch, MAEd, for coordinating practice visits and data. Dr Phillips was supported by the Theodore J. Phillips Endowed Professorship in Family Medicine.

CORRESPONDING AUTHOR: Address correspondence to Dr William R. Phillips, Department of Family Medicine, Box 345390 University of Washington, Seattle, WA 98195. 206-543-9425.wphllps@uw.edu.

\section{References}

1. Institute of Medicine Committee on the Health Professions Education Summit. Health professions education; a bridge to quality. Greiner AC, Knebel E, eds. Washington, DC: National Academies Press; 2003.

2. World Health Organization. Framework for action on interprofessional education and collaborative practice. WHO/HRH/HPN/10.3. Geneva, Switzerland: WHO; 2006.

3. Abu-Rish E, Kim S, Choe L, et al. Current trends in interprofessional education of health sciences students: a literature review. J Interprof Care. 2012;26(6):444-451.

4. Everard KM, Crandall S, Blue A, Rottnek F, Pole D, Mainous AG III. Exploring interprofessional education in the family medicine clerkship: a CERA study. Fam Med. 2014;46(6):419422 .
5. Brandt B, Lutfiyya MN, King JA, Chioreso C. A scoping review of interprofessional collaborative practice and education using the lens of the Triple Aim. J Interprof Care. 2014;28(5):393-399.

6. Starfield B, Shi L, Macinko J. Contribution of primary care to health systems and health. Milbank Q. 2005;83(3):457-502.

7. Hammick M, Freeth D, Koppel I, Reeves S, Barr H. A best evidence systematic review of interprofessional education: BEME Guide no. 9. Med Teach. 2007;29(8):735-751.

8. Zaudke JK, Paolo A, Kleoppel J, Phillips C, Shrader S. The impact of an interprofessional practice experience on readiness for interprofessional learning. Fam Med. 2016;48(5):371376.

9. Reeves S, Perrier L, Goldman J, Freeth D, Zwarenstein M. Interprofessional education: effects on professional practice and healthcare outcomes (update). Cochrane Database Syst Rev. 2013;(3):CD002213. 